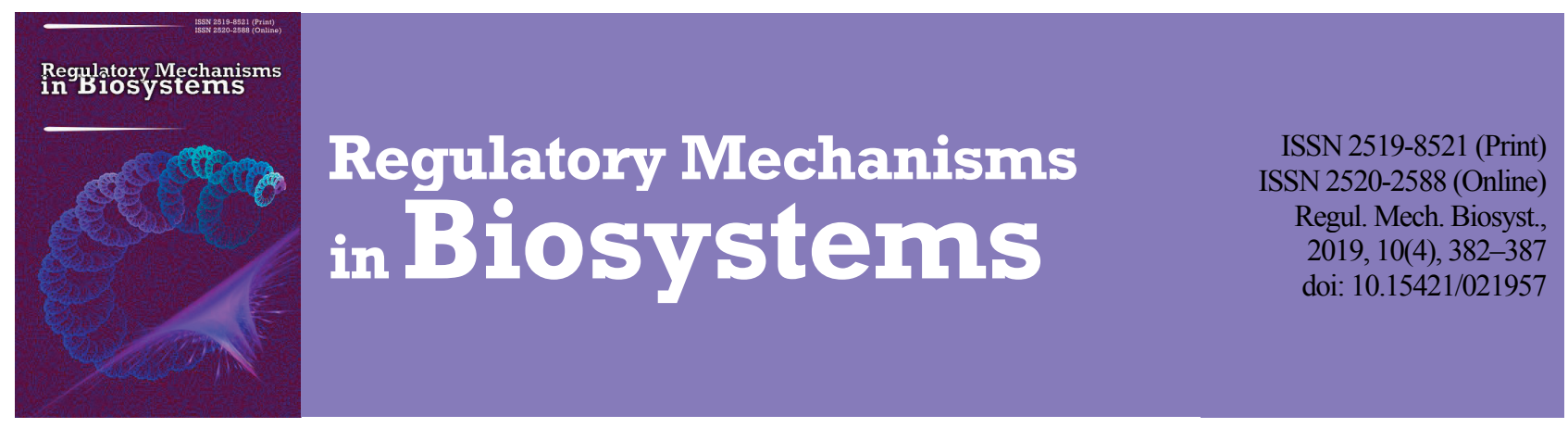

\title{
Microscopic features of lamina muscularis mucosae of the goose gut
}

\author{
M. M. Kushch, L. L. Kushch, I. A. Fesenko, O. S. Miroshnikova, O. V. Matsenko \\ Kharkiv State Zooveterinary Academy, Mala Danylivka, Ukraine
}

Article info

Received 08.09.2019

Received in revised form 07.10 .2019

Accepted 10.10.2019

Kharkiv State

Zooveterinary Academ

Akademichna st., 1 ,

Mala Danylivka,

Dergachi district,

Kharkiv region,

62341, Ukraine.

Tel.: +38-057-635-75-27.

E-mail:

dr.kushch@meta.ua

\author{
Kushch, M. M., Kushch, L. L., Fesenko, I. A., Miroshnikova, O. S., \& Matsenko, O. V. (2019). Microscopic features of lamina \\ muscularis mucosae of the goose gut. Regulatory Mechanisms in Biosystems, 10(4), 382-387. doi:10.15421/021957
}

The aim of work was to determine the features of the microscopic structure of the lamina muscularis mucosae of the goose gut during the postnatal ontogenesis. According to the review of the literature, during the characterisation of the structure of the intestinal muco$\mathrm{sa}$, researchers first pay attention to the condition of the villi, crypts, epithelial layer and their morphometric parameters, leaving the lamina muscularis mucosae aside. The intestinal lamina muscularis mucosae is an under-researched structure of the intestinal wall, the information on which is fragmentary and contradictory. The middle parts of the duodenum, jejunum, ileum, cecum and rectum of large grey geese of 13 age groups were investigated. The classic histological methods of staining by hematoxylin and eosin, aniline blue orange (by Mallory), as well as azure II - eosin were used. It was established that the lamina muscularis mucosae of the goose's small intestine is formed by two layers of unstriated muscle tissue: internal and external. In contradistinction to mammals, the thicker inner layer of the LMM has not a circular, but a longitudinal direction of cell location while by contrast the thinner outer layer is located in a circular direction. According to results of our research, the thickness of the lamina muscularis mucosae of the small intestine of the geese rapidly increased with age. The thickness of the duodenum corresponded to the value of adult geese at 60 days of age; jejunum, ileum, and rectum - at 21 days, cecum - at 7 days age. The lamina muscularis mucosae was thinnest in the duodenum, and it was thickest in the ileum. The lamina muscularis mucosa of the large intestine of geese is represented by only one longitudinal layer. By contrast, the thinner outer layer is located in a circular direction. Detailed information of the microscopic structure of the lamina muscularis mucosae of the intestine of geese can be useful for specialists, both morphologists and physiologists, for analyzing the histological preparations of the intestine of birds by the action of biotic and abiotic factors, as well as a basis of comparison with such structure in other species of animals. The description of the construction of this important microscopic structure of the intestine can serve a morphological basis for elucidating its function.

Keywords: birds; microscopic structure; digestive organs.

\section{Introduction}

According to the classic ideas, the lamina muscularis mucosae (LMM) of the stomach and gut of mammals, including humans, is located between its lamina propria and the submucosal basis. It consists of two layers: the inner and outer, respectively, with a predominantly circular and longitudinal orientation of unstriated muscle cells (BruhinFeichter et al., 2012; Bello \& Danmaigoro, 2019). Despite the fact that the LMM is a constituent element of the alimentary canal, researchers pay little attention to it. Besides, the physiological significance of LMM remains understood only at the level of hypothesis (Kuriyama et al., 1998; Grundy et al., 2006). It is known that the motor activity of LMM of the alimentary canal of animals has differences both in different biological species, and in its different parts (Kamikawa et al., 1985). Pathophysiological changes of motor activity of LMM can change the antibacterial barrier of mucosa (Percy et al., 1998). It is different from the layers of the muscular tunic by type of intercellular contacts and blood supply, autonomic innervation and pharmacological sensitivity and bioelectric activity. A large number of mast cells were found in the LMM of the rat's ileum, but not in the muscular tunic. Cultivation of muscle cells of LMM was unsuccessful, and characteristics of their ion channels according to electrophysiological results are not established (Uchida \& Kamikawa, 2007). The status of the LMM of the transplanted intestine is important during the transplantation to the recipient (Websky et al., 2015). Due to human Crohn's disease, hyperplasia of the muscle tissue of the bowel has a direct correlation with general inflammation, and LMM with acute inflammation of the submucosa
(Chen et al., 2017). The degree of development of the LMM of the intestine is influenced by the tone of the autonomic nervous system. Compared to sympathicotonic hens, the sympathico-normotonic hens had a greater volume of LMM in the duodenum and the jejunum. Due to dysbiosis, the thickness of LMM of hens becomes smaller (Teirlynck et al., 2011). A $50 \%$ limitation in the amount of food given to rats caused thickening of the colon along with a thickening of its own lamina (Schoffen et al., 2014).

Information about features of structure of the LMM of the avian gut, including poultry, is fragmentary and sometimes contradictory. The fact of the presence of LMM in the gut of birds is often indicated only: in the helmeted guinea fowl (Numida meleagris) (Singh et al., 2017) and in the Japanese quail (Coturnix japonica) (Wilkinson et al., 2018). A number of researchers speak about the absence of LMM of the gut: in the African pied crow (Corvus albus) (Igwebuike et al., 2010) and feral pigeon (Columba livia) (Udoumoh, 2016). In connection with absence of LMM, the intestinal mucosa of quail and broiler chickens is represented only by a simple columnar epithelium and lamina propria. At the same time, its muscular tunic consists of three layers: internal longitudinal, middle circular and outer longitudinal (Kachave et al., 2009).

According to other researchers, there is only one layer of smooth muscle cells in the small intestine LMM: Trifonov \& Kuleshov (2008) in the domestic hen, Khaleel \& Atiea (2017) in domestic duck. According to Al-Saffar \& Al-Samawy (2016), in the striated scops owl (Otus brucei) LMM is found only in the duodenum and is absent in the jejunum and ileum. According to Trifonov \& Kuleshov (2008), the thickness of LMM is 8-15 $\mu \mathrm{m}$ in a one-day bird, and $15-30 \mu \mathrm{m}$ and 10 
$30 \mu \mathrm{m}$ in geese of 8 weeks and 6 months age respectively. In chickens, the thickness of lamina muscularis increases in proportion to age. It varies in the same range in the duodenum, jejunum and cecum, but it is thicker in the ileum and rectum (Kuleshov, 2010). The LMM of the goose gut is well expressed. Separate bundles of unstriated muscle cells enter to the tops of folds and villi (Strizhikov et al., 2007).

The LMM of the small intestine of the cattle egret (Bubulcus ibis), black winged kite (Elanus caeruleus) and mulard (Cairina moschata $\times$ Anas platyrhynchos) is represented by two layers: the inner (wide), and the outer (narrow). The inner layer has bundles which are vertically oriented towards its proper lamina and which stretch to the tops of villi. The outer layer is formed by longitudinally oriented unstriated muscle cells close to the submucosal basis (Kachave et al., 2009; Hussein \& Rezk, 2016; Al-Samawy et al., 2017).

The LMM of the gut of the African ostrich (Struthio camelus) consists of two layers: longitudinal and circular oriented bundles of unstriated muscle cells. The circular bundles of the large intestine enter into the circular folds and stroma of the intestinal villi (Bezuidenhout, 1990).

The LMM of large intestine has the form of longitudinally oriented bundles of unstriated muscle cells, which stretch in the folds in form of vertical pillars in the African pied crow (Corvus albus) (Igwebuike \& Eze, 2010), cattle egret (Bubulcus ibis) (Hussein \& Rezk, 2016) and domestic hen (Pandit et al., 2018). The LMM of the goose rectum is divided by layers of loose connective tissue, which consist of nerve elements, whereby it is double-layer (Strizhikov et al., 2007).

The majority of intestinal morphological studies are devoted to the influence of various environmental factors on its structure, using the following known markers characterizing its functional state: thickness of the mucous membrane and its layers, height of villi, depth of crypts, surface area of villi. The LMM remains unaddressed. The peculiarities of the structure of LMM in birds are not thoroughly researched and, sometimes, mechanically transferred from those of mammals. Therefore, taking into account the contradictory information regarding the microscopic structure of LMM in the gut of birds, this issue is not yet fully resolved and needs to be thoroughly researched.

The purpose of the paper was to fill this gap and draw the attention of researchers to such an important structure of the bowel of geese as LMM in its various sections during the postnatal ontogeny period. The main elements of the study were to find out the number of layers in the LMM, determine their thickness at different stages of postnatal ontogeny, the direction of placement of smooth muscle cells in them, as well as the presence or expression of the submucosal basis.

\section{Materials and methods}

The research was conducted at the department of anatomy and histology of the Faculty of Veterinary Medicine in the Kharkiv State Zooveterinary Academy, Ukraine. The protocol of the studies was agreed with the local ethics committee of the Kharkiv State Zooveterinary Academy. During the experimental studies, all manipulations with animals that were involved in the experiment were conducted in accordance with the European Convention on the Protection of Vertebrate Animals used for Experimental and Scientific Purposes (Strasbourg, 1986) and the General Ethical Principles of Animal Experiments, adopted by the First National Congress of Bioethics (Kyiv, 2001). The birds were decapitated under light ether anesthesia.

The conditions of maintenance were standard. All geese were clinically healthy, received standard granular feed. Material for research was selected from the large grey breed domestic geese (Anser anser). There were formed into 13 groups of the following ages: 1, 3, 7, 14, 21, 30, 60, $180,240,365,730,1195$ and 1825 days old.

The portions of the middle regions of duodenum, jejunum, ileum, cecum and rectum of 5 geese of each age group were selected for histological studies. These were fixed by $10 \%$ solution of neutral formalin and embed into paraffin. The histological slides of gut were stained by hematoxylin and eosin, aniline blue - orange (by Mallory), as well as azure II - eosin. The investigations of histological slides were performed using light microscopes Jenamed 2. Determination of the thickness of intestinal LMM was carried out using an ocular grid. The parameters of geese older than 240 days were determined by indices of the LMM thickness of the gut of adult birds. We used the parameter of average age indicator of the gut - middle age point (MAP) (Kushch, 2015) in order to generalize comparative estimation of size and development of LMM of each gut. The mean age indicator of the LMM thickness of each gut was defined as the arithmetic mean of the values of its 13 age indices.

The experimental data analysis was performed using the ANOVA method. Differences between the values in the different age groups were determined using the Tukey test, where the differences were considered reliable at $\mathrm{P}<0.05$ (taking into account the Bonferroni correction). The numerical data in the tables are presented as $\mathrm{x} \pm \mathrm{SD}$.

\section{Results}

The LMM of goose gut is formed by unstriated muscle tissue. It consists of two layers (internal and external) in the small intestine (Fig. 1).

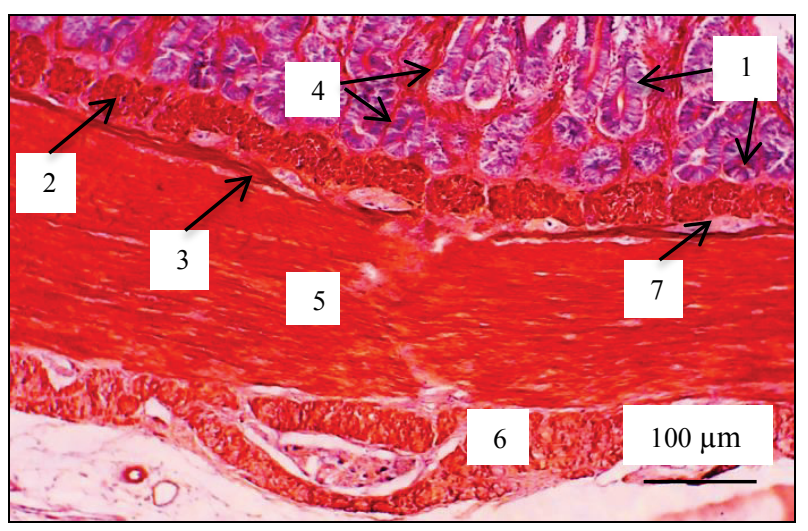

Fig. 1. Light micrograph of wall of the ileum of a 180 day old goose of (cross-section), azure II - eosin: 1 - crypts, 2 - inner layer of LMM, 3 - outer layer of LMM; 4 - pillars of unstriated muscle cells (between crypts); 5 -inner layer of muscular tunic, 6 - outer layer of muscular tunic; 7-submucosal nerve node

The bundles of unstriated muscle cells of the thicker inner layer are located in a longitudinal direction, and the thinner outer layer - in a circular direction. The layers of the LMM are separated by thin layers of loose connective tissue, in which the elements of submucosal nerve plexus (nerve nodes and bundles of nerve fibers) are located.

The inner layer of the LMM is clearly expressed. It is located directly under the base of the crypt and has the appearance of a wide oxyphilic stained strip. The narrow strips of unstriated muscle tissue originate from the inner layer of LMM. They are located between the crypts and stretching to the tops of the villi.

The outer layer of the LMM is poorly developed. In this connection, it is not always possible to differentiate it on histological slides of the intestinal wall, stained with hematoxylin and eosin (Fig. 2).

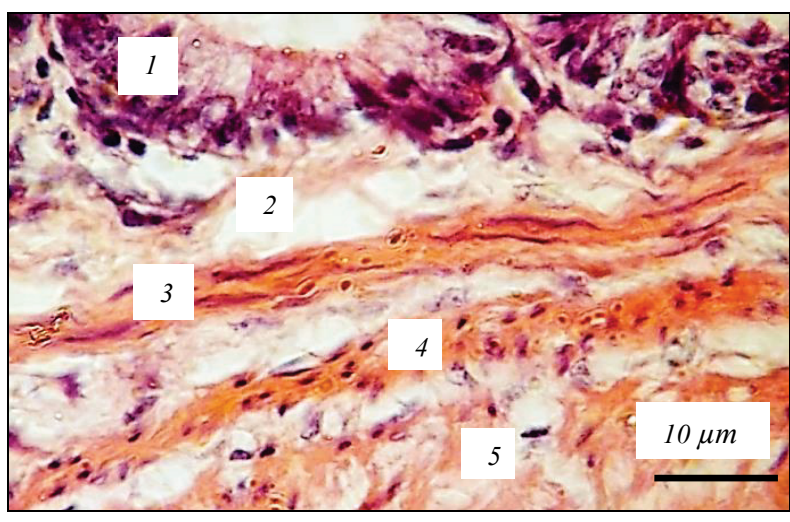

Fig. 2. Light micrograph of wall of the jejunum of a 1,195 day old goose (longitudinal section), hematoxylin and eosin: 1 - epithelium 
of crypt, 2-lamina propria of mucosa; 3 - inner layer of LMM,

4 - outer layer of LMM, 5 - inner layer of muscular tunic

It is more clearly distinguished on the histological slides of gut staining azure II - eosin, as well as by Mallory (Fig. 3).

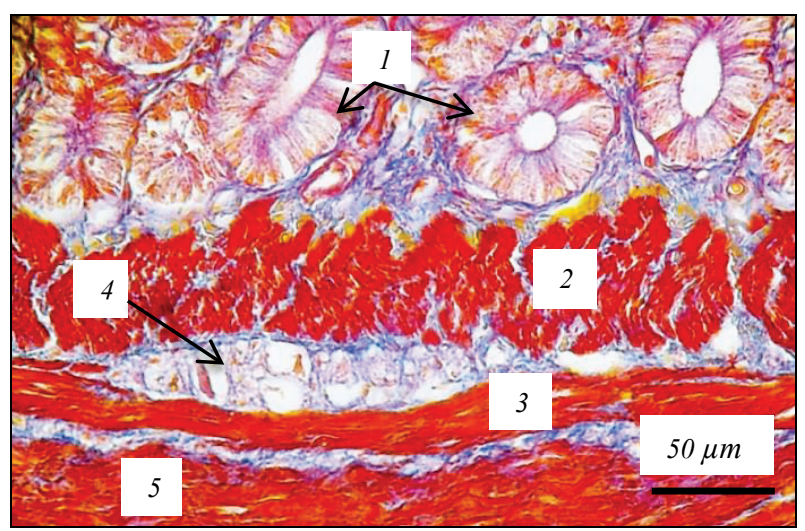

Fig. 3. Light micrograph of wall of the ileum of a 21 day old goose, staining by Mallory: 1 - epithelium of crypt; 2 - inner layer of LMM; 3 - outer layer of LMM; 4 - ganglion of submucosal nerve plexus; 5 - inner layer of muscular tunic

The thickness of the LLM of the duodenum of the goose gut gradually increases with age (Table 1). The mean age parameter (MAP) of the thickness of LMM of duodenum was $34.1 \pm 5.47 \mu \mathrm{m}$. The relative thickness of the layers of LMM changed with age. The pattern of thickness of LMM was its increasing in the inner layer from $56.8 \%$ in 3 day to $70.7 \%$ at 60 day old geese and, accordingly, decreasing in the external layer. The relative thickness of the inner layer was smaller and equalled $64.1-64.8 \%$ in $1,195-1,255$ day old geese.

\section{Table 1}

Thickness of the lamina muscularis mucosae of duodenum of geese $1-1,825$ days old $(\mathrm{x} \pm \mathrm{SD}, \mathrm{n}=5)$

\begin{tabular}{lcccc}
\hline Age, day & $\begin{array}{c}\text { Inner } \\
\text { layer, } \mu \mathrm{m}\end{array}$ & $\begin{array}{c}\text { Outer } \\
\text { layer, } \mu \mathrm{m}\end{array}$ & $\begin{array}{c}\text { Total, } \\
\mu \mathrm{m}\end{array}$ & $\begin{array}{c}\text { Relative thickness } \\
\text { of inner layer, } \%\end{array}$ \\
\hline 1 & $12.5 \pm 1.52^{\mathrm{a}}$ & $7.2 \pm 1.41^{\mathrm{a}}$ & $19.7 \pm 1.68^{\mathrm{a}}$ & 63.5 \\
3 & $11.3 \pm 1.17^{\mathrm{a}}$ & $8.6 \pm 1.21^{\mathrm{a}}$ & $19.9 \pm 1.43^{\mathrm{a}}$ & 56.8 \\
7 & $12.8 \pm 1.84^{\mathrm{a}}$ & $9.6 \pm 0.69^{\mathrm{a}}$ & $22.4 \pm 1.45^{\mathrm{a}}$ & 57.0 \\
14 & $21.8 \pm 0.74^{\mathrm{b}}$ & $10.9 \pm 0.99^{\mathrm{a}}$ & $32.8 \pm 2.46^{\mathrm{b}}$ & 66.7 \\
21 & $18.4 \pm 2.71^{\mathrm{b}}$ & $11.3 \pm 1.43^{\mathrm{a}}$ & $29.7 \pm 2.15^{\mathrm{ab}}$ & 61.8 \\
30 & $28.7 \pm 4.14^{\mathrm{c}}$ & $12.9 \pm 1.23^{\mathrm{a}}$ & $41.6 \pm 4.08^{\mathrm{c}}$ & 68.9 \\
60 & $27.0 \pm 5.04^{\mathrm{bc}}$ & $11.2 \pm 0.94^{\mathrm{a}}$ & $38.2 \pm 3.62^{\mathrm{bc}}$ & 70.7 \\
180 & $26.7 \pm 4.61^{\mathrm{c}}$ & $13.4 \pm 0.85^{\mathrm{a}}$ & $40.1 \pm 3.89^{\mathrm{c}}$ & 66.7 \\
240 & $27.8 \pm 3.25^{\mathrm{c}}$ & $14.2 \pm 1.08^{\mathrm{a}}$ & $42.0 \pm 4.49^{\mathrm{c}}$ & 66.2 \\
365 & $31.8 \pm 2.42^{\mathrm{c}}$ & $13.1 \pm 0.94^{\mathrm{a}}$ & $44.9 \pm 4.74^{\mathrm{c}}$ & 70.9 \\
730 & $29.6 \pm 5.09^{\mathrm{c}}$ & $12.9 \pm 0.94^{\mathrm{a}}$ & $42.5 \pm 3.89^{\mathrm{c}}$ & 69.7 \\
1195 & $22.3 \pm 4.86^{\mathrm{bc}}$ & $12.2 \pm 0.96^{\mathrm{a}}$ & $34.8 \pm 3.73^{\mathrm{bc}}$ & 64.1 \\
1825 & $22.6 \pm 4.37^{\mathrm{bc}}$ & $12.3 \pm 1.12^{\mathrm{a}}$ & $34.9 \pm 3.89^{\mathrm{bc}}$ & 64.8 \\
\hline
\end{tabular}

Note: different letters indicate values which reliably differed one from another within one column of table according to the results of comparison using Tukey test with Bonferroni correction.

The thickness of the LLM of jejunum as with the duodenum of the goose gut gradually increased with age; it approximates to the values of adult poultry $(79.4 \pm 5.31 \mu \mathrm{m})$ at 180 days old (Table 2$)$. The MAP of thickness of LMM of the jejunum was $51.9 \pm 9.23 \mu \mathrm{m}$. It was larger than in the duodenum by $52.2 \%(\mathrm{P}<0.05)$. The relative thickness of the inner and outer layers of LMM of the jejunum varied with age. The general pattern of changes was reduction in the thickness of the inner layer (from $80.6 \%$ at 3 days to $55.6 \%$ at 1,825 days old) and, accordingly, increase in the thickness of the outer layer.

The thickness of LMM of the ileum increased unevenly with the birds' age. It approximates to the values of adult birds $(58.6 \pm 2.96 \mu \mathrm{m})$ at 21 days old (Table 3). The MAP of thickness of the LMM was higher than this indicator of the jejunum by $17.6 \%$ and was equaled $61.1 \pm$ $12.59 \mu \mathrm{m}$ for $240-730$ day old geese.
Throughout the observation period, the relative thickness of the inner layer of LMM of the ileum fluctuated from $64.4 \%$ to $79.7 \%$. The relative thickness of the inner layer of LMM of the jejunum had higher values and equaled $70.2-79.7 \%$ for geese $30-1195$ days old.

Table 2

Thickness of lamina muscularis mucosae of the jejunum of geese $1-1825$ days old $(x \pm S D, n=5)$

\begin{tabular}{lcccc}
\hline Age, day & $\begin{array}{c}\text { Inner } \\
\text { layer, } \mu \mathrm{m}\end{array}$ & $\begin{array}{c}\text { Outer } \\
\text { layer, } \mu \mathrm{m}\end{array}$ & $\begin{array}{c}\text { Total, } \\
\mu \mathrm{m}\end{array}$ & $\begin{array}{c}\text { Relative thickness } \\
\text { of inner layer, } \%\end{array}$ \\
\hline 1 & $20.4 \pm 3.09^{\mathrm{a}}$ & $6.2 \pm 0.69^{\mathrm{a}}$ & $26.6 \pm 3.38^{\mathrm{a}}$ & 76.6 \\
3 & $21.5 \pm 2.42^{\mathrm{a}}$ & $6.1 \pm 0.54^{\mathrm{a}}$ & $27.7 \pm 1.03^{\mathrm{a}}$ & 80.6 \\
7 & $31.4 \pm 2.51^{\mathrm{a}}$ & $10.2 \pm 1.05^{\mathrm{b}}$ & $41.6 \pm 1.88^{\mathrm{b}}$ & 75.4 \\
14 & $30.9 \pm 4.30^{\mathrm{a}}$ & $11.9 \pm 0.76^{\mathrm{b}}$ & $42.7 \pm 2.49^{\mathrm{b}}$ & 72.3 \\
21 & $40.9 \pm 7.71^{\mathrm{a}}$ & $14.0 \pm 0.72^{\mathrm{b}}$ & $54.9 \pm 2.96^{\mathrm{c}}$ & 74.5 \\
30 & $38.5 \pm 11.75^{\mathrm{a}}$ & $14.5 \pm 1.64^{\mathrm{b}}$ & $52.9 \pm 2.84^{\mathrm{c}}$ & 72.6 \\
60 & $42.1 \pm 2.51^{\mathrm{a}}$ & $17.4 \pm 1.59^{\mathrm{b}}$ & $59.5 \pm 4.86^{\mathrm{c}}$ & 70.8 \\
180 & $56.1 \pm 3.32^{\mathrm{b}}$ & $23.3 \pm 2.06^{\mathrm{c}}$ & $79.4 \pm 5.31^{\mathrm{d}}$ & 70.7 \\
240 & $39.2 \pm 4.30^{\mathrm{a}}$ & $24.9 \pm 2.29^{\mathrm{c}}$ & $64.2 \pm 5.42^{\mathrm{c}}$ & 61.1 \\
365 & $43.1 \pm 6.32^{\mathrm{ab}}$ & $24.1 \pm 1.88^{\mathrm{c}}$ & $65.0 \pm 5.02^{\mathrm{c}}$ & 63.0 \\
730 & $38.5 \pm 11.49^{\mathrm{ab}}$ & $21.3 \pm 2.15^{\mathrm{c}}$ & $59.8 \pm 5.20^{\mathrm{c}}$ & 64.3 \\
1195 & $23.4 \pm 2.31^{\mathrm{a}}$ & $23.9 \pm 1.05^{\mathrm{c}}$ & $47.3 \pm 4.52^{\mathrm{bc}}$ & 49.5 \\
1825 & $29.6 \pm 3.02^{\mathrm{a}}$ & $23.7 \pm 1.97^{\mathrm{c}}$ & $53.2 \pm 5.31^{\mathrm{c}}$ & 55.6 \\
\hline
\end{tabular}

Note: see Table 1.

Table 3

Thickness of the lamina muscularis mucosae of ileum of geese $1-1825$ days old $(x \pm S D, n=5)$

\begin{tabular}{lcrcc}
\hline Age, day & $\begin{array}{c}\text { Inner } \\
\text { layer, } \mu \mathrm{m}\end{array}$ & $\begin{array}{c}\text { Outer } \\
\text { layer, } \mu \mathrm{m}\end{array}$ & $\begin{array}{c}\text { Total, } \\
\mu \mathrm{m}\end{array}$ & $\begin{array}{c}\text { Relative thickness } \\
\text { of inner layer, } \%\end{array}$ \\
\hline 1 & $18.1 \pm 2.49^{\mathrm{a}}$ & $10.0 \pm 1.05^{\mathrm{a}}$ & $28.1 \pm 2.78^{\mathrm{a}}$ & 64.4 \\
3 & $26.3 \pm 0.92^{\mathrm{a}}$ & $9.1 \pm 0.85^{\mathrm{a}}$ & $35.4 \pm 3.38^{\mathrm{a}}$ & 74.3 \\
7 & $29.7 \pm 3.74^{\mathrm{a}}$ & $9.0 \pm 0.99^{\mathrm{a}}$ & $38.7 \pm 2.87^{\mathrm{a}}$ & 76.8 \\
14 & $32.5 \pm 2.42^{\mathrm{a}}$ & $13.5 \pm 1.46^{\mathrm{b}}$ & $46.0 \pm 3.40^{\mathrm{a}}$ & 70.7 \\
21 & $42.2 \pm 6.43^{\mathrm{a}}$ & $16.3 \pm 1.45^{\mathrm{b}}$ & $58.6 \pm 2.96^{\mathrm{b}}$ & 72.2 \\
30 & $71.1 \pm 2.49^{\mathrm{b}}$ & $18.1 \pm 1.41^{\mathrm{b}}$ & $89.2 \pm 6.43^{\mathrm{c}}$ & 79.7 \\
60 & $66.6 \pm 0.92^{\mathrm{b}}$ & $18.4 \pm 1.55^{\mathrm{b}}$ & $85.0 \pm 6.00^{\mathrm{c}}$ & 78.4 \\
180 & $64.6 \pm 6.59^{\mathrm{b}}$ & $19.2 \pm 1.66^{\mathrm{b}}$ & $83.8 \pm 7.44^{\mathrm{c}}$ & 77.0 \\
240 & $53.7 \pm 6.05^{\mathrm{ab}}$ & $18.4 \pm 1.41^{\mathrm{b}}$ & $72.0 \pm 5,82^{\mathrm{d}}$ & 74.5 \\
365 & $52.2 \pm 6.59^{\mathrm{ab}}$ & $17.9 \pm 1.61^{\mathrm{b}}$ & $70.0 \pm 6.65^{\mathrm{d}}$ & 74.5 \\
730 & $61.1 \pm 8.60^{\mathrm{b}}$ & $17.0 \pm 1.34^{\mathrm{b}}$ & $78.0 \pm 6.76^{\mathrm{cd}}$ & 78.3 \\
1195 & $39.1 \pm 7.06^{\mathrm{a}}$ & $16.7 \pm 1.46^{\mathrm{b}}$ & $55.8 \pm 4.93^{\mathrm{ab}}$ & 70.2 \\
1825 & $35.2 \pm 6.14^{\mathrm{a}}$ & $18.1 \pm 1.68^{\mathrm{b}}$ & $53.2 \pm 3.74^{\mathrm{ab}}$ & 66.1 \\
\hline
\end{tabular}

Note: see Table 1 .

Unlike the small intestine, the LMM of the large intestine of geese is represented by a single layer of unstriated muscle cells with a longitudinal location (Fig. 4). Thin strips of unstriated muscle tissue stretched from the LMM in the folds of the mucosa between the crypts. These strips became thicker in the composition of villi.

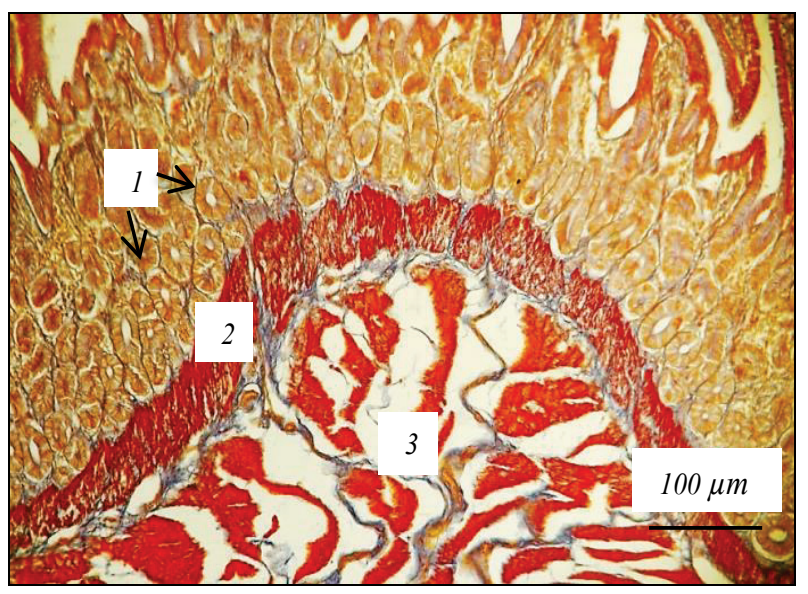

Fig. 4. Light micrograph of wall of the rectum of a 30 day old goose, staining by Mallory: 1 - crypts; 2 - lamina muscularis mucosae; 3 -inner layer of muscular tunic 
The thickness of the LMM was uneven in the individual sections of the large intestine. It was narrow for the cecum and wide for the rectum (Table 4). The thickness of LMM of the cecum increased for 7 day old geese by $73.4 \%(\mathrm{P}<0.05)$ and reached the maximum value of $15.9 \pm$ $1.84 \mu \mathrm{m}$. This indicator ranged from 14.1 to $16.1 \mu \mathrm{m}$ for $21-730$ day old geese and it was smaller $(9.3-9.5 \mu \mathrm{m})$ for $1,195-1,825$ day old geese. The MAP of the thickness of LMM of the cecum was smaller (12.7 \pm $1.90 \mu \mathrm{m})$ by 4.81 times $(\mathrm{P}<0.05)$ than its indicator for the ileum.

\section{Table 4}

The thickness of the lamina muscularis mucosae of large intestine of $1-1825$ day old geese $(x \pm S D, n=5)$

\begin{tabular}{lcc}
\hline \multicolumn{1}{c}{ Age, day } & Cecum, $\mu \mathrm{m}$ & Rectum, $\mu \mathrm{m}$ \\
\hline 1 & $7.0 \pm 1.55^{\mathrm{a}}$ & $23.4 \pm 3.07^{\mathrm{a}}$ \\
3 & $9.1 \pm 0.94^{\mathrm{a}}$ & $29.4 \pm 4.64^{\mathrm{a}}$ \\
7 & $15.9 \pm 1.84^{\mathrm{b}}$ & $30.2 \pm 4.03^{\mathrm{a}}$ \\
14 & $15.1 \pm 1.97^{\mathrm{b}}$ & $31.9 \pm 4.46^{\mathrm{a}}$ \\
21 & $14.8 \pm 1.66^{\mathrm{b}}$ & $52.4 \pm 7.33^{\mathrm{b}}$ \\
30 & $14.3 \pm 1.55^{\mathrm{b}}$ & $49.4 \pm 5.31^{\mathrm{b}}$ \\
60 & $14.1 \pm 2.64^{\mathrm{b}}$ & $49.2 \pm 2.96^{\mathrm{b}}$ \\
180 & $14.3 \pm 2.98^{\mathrm{b}}$ & $50.5 \pm 5.98^{\mathrm{b}}$ \\
240 & $16.1 \pm 2.35^{\mathrm{b}}$ & $45.4 \pm 6.23^{\mathrm{b}}$ \\
365 & $14.8 \pm 1.66^{\mathrm{b}}$ & $52.4 \pm 4.03^{\mathrm{b}}$ \\
730 & $11.3 \pm 2.29^{\mathrm{ab}}$ & $59.4 \pm 7.33^{\mathrm{b}}$ \\
1195 & $9.3 \pm 3.34^{\mathrm{ab}}$ & $59.3 \pm 8.60^{\mathrm{b}}$ \\
1825 & $9.5 \pm 2.28^{\mathrm{ab}}$ & $53.2 \pm 5.58^{\mathrm{b}}$ \\
\hline
\end{tabular}

Note: see Table 1.

The thickness of LMM of the rectum reached the value of adult geese $(52.4 \pm 7.33 \mu \mathrm{m})$ in the 1 day old birds. Later it ranged from $49.4 \mu \mathrm{m}$ (for 30 day old geese) to $53.2 \mu \mathrm{m}$ (for 1,825 days old geese). The MAP of the thickness of LMM of the rectum $(47.5 \pm 9.79 \mu \mathrm{m})$ was higher by 3.7 times $(\mathrm{P}<0.05)$ than that indicator of the cecum.

\section{Discussion}

It is necessary to constantly monitor the health of birds' intestines due to the conditions of today's intensive poultry management. It is important to search for appropriate markers of gut condition (Ducatelle, 2018), which is impossible without a detailed understanding of its microscopic structure. The morphometric indices of intestinal structures are an important indicator of productivity of poultry used in breeding (Schmidt et al., 2009; Alshamy et al., 2012). The condition of the intestinal mucosa determines almost all its major functions (Lilburn \& Loeffler, 2015; Okpe et al., 2016).

One of the under-researched structures of the intestinal wall of both mammals and birds is LMM (Uchida \& Kamikawa, 2007). It is known that the LMM consists of two layers of unstriated muscle tissue in mammals, including humans (Bruhin-Feichter et al., 2012). Despite the fact that the LMM is a component of the mucosa of almost the entire alimentary canal, researchers pay little attention to it (Kuriyama et al., 1996; Grundy et al., 2006). It is not surprising that it was called "the forgotten sibling" in one of the few articles devoted to the structure and function of LMM (Uchida \& Kamikawa, 2007). It is established that the LMM provides movement of the villi, participates in the processes of absorption, secretion, and protection. Therefore changes in its activity may cause a violation of the corresponding functions of the gut (Greenwood \& Davison, 1987). Like muscular tunic, it is constructed of unstriated muscle tissue, but differs significantly by bioelectric activity and participation in pathological processes of the intestinal wall (Van Montfrans et al., 2002; Lembo, \& Camilleri, 2003).

Our studies established that the LMM of the goose gut has a characteristic structure, but its expressiveness and architectonics in different sections are unequal. It is formed by two layers of unstriated muscle tissue (internal and external) in the small intestine. The external layer is poorly developed. Unlike mammals (King et al., 1947; Bello \& Danmaigoro, 2019), the thicker inner layer of the LMM has a longitudinal direction of cell location, and the thinner outer layer has a circular direction. Such features of the location of smooth muscle cells can probably be explained by the peculiarities of the digestive processes among birds. The results of our research on the two layers of LMM of the goose's small intestine confirm the information obtained regarding chickens (Gabella, 1985), ostriches (Bezuidenhout, 1990), mulards (Al-Samawy et al., 2017), some species of wild birds: cattle egret (Bubulcus ibis) (Hussein \& Rezk, 2016), black-winged kite (Elanus caeruleus) (Kachave et al., 2009), and contradicts information according to which the small intestine LMM is represented by only one longitudinal layer: in goslings (Liu et al., 2010), hens (Trifonov \& Kuleshov, 2008; Khalid, 2014), ducks (Khaleel \& Atiea 2017). According to research (Igwebuike \& Eze, 2010), the mucous membrane of the small intestine of the African pied crow (Corvus albus) contains no muscle plate at all.

According to results of our research, the thickness of the LMM of the small intestine of geese increased rapidly with age, acquiring the features of adult birds at an early age. It corresponded to the value of adult birds in the duodenum at 60 days old, in the jejunum and ileum at 21 day old. Such asynchrony of LMM development both in embryonic and post-embryonic ontogeny in individual intestines is a characteristic feature of other intestinal structures, which is evidenced by the indicators such as the villi height and volume, number of enterocytes per villus, which is indicated in their research by Uni et al. (1995), Chin et al. (2017). It is the presence of a reliable difference with the previous age, which observed at the age of 14 and 30 days in the duodenum, at the age of 7,21 and 180 days - in the jejunum, at the age of 21 and 30 days - in the ileum, at the age of 21 days - in the rectum (as well as at a later age of geese) which indicates precisely such asynchrony. As shown by the middle age point (the MAP), the thickness of the LMM was smallest in the duodenum, and largest in the ileum. At the age of 365-1,825 days, it was determined within the range of 34.8$44.9 \mu \mathrm{m}$ for the duodenum, $47.3-65.0 \mu \mathrm{m}$ for the jejunum, 53.2$70.0 \mu \mathrm{m}$ for the ileum.

The LMM of the large intestine of geese is represented by only one longitudinal layer, from which the bundles of unstriated muscle cells enter into folds and villi. Its thickness increased with age. It corresponded to the value of adult birds at 7 days old for the cecum, and at 21 days old for the rectum. At the same time, according to Bezuidenhout (1990), LMM of the large intestine of the ostrich consists of two layers; the dove it is absent in the cecum (Udoumoh, 2016).

The acquisition of intestinal LMM by goslings along with other microscopic structures of the thickness of adult birds (7-60 days of age) indicates the importance of the formation of this digestive organ, which ensures the fulfillment of its important functions (digestion, nutrient absorption, immune protection, etc.) in the early stages of the postnatal ontogeny period (China et al., 2017). Early intestine development is important for maximizing growth potential. Thicker LMM is an indicator of intestine maturity (Cheled-Shoval et al., 2011).

The presence of two layers of LMM in the thin compartment and one layer in the thick compartment of the bird's intestine might be associated with their functional features and the corresponding nature of the contractions, which provides shape change of the villi, the processes of absorption. Even slight differences in organ structure cause significant changes in their function (Verdal et al., 2010).

Considering the information concerning the LMM of birds' intestines, it is worth noting such a structure as the submucosal base with which it borders. As is known, the submucosa of the intestinal wall of mammals is well developed (Tootian et al., 2012). Its loose fibrous connective tissue is rich in elastic fibers and fat cells, contains elements of submucosal venous, lymphatic and nerve plexuses, cluster of lymphoid tissue. The submucosa of the duodenum has digestive duodenal glands (Accogli et al., 2018). Literature sources about the submucosal base of the gut of birds are ambiguous.

Some researchers point to its presence: in domestic hens (Casteleyn et al., 2010; Kuleshov, 2010; Pandit et al., 2018), in the African pied crow (Igwebuike \& Eze, 2010), in the domestic goose (Liu et al., 2010), striated scope owls (Otus brucei) (Al-Saffar \& Al-Samawy, 2016), guinea fowl (Singh et al., 2017), others point to its absence in domestic hens (Hodges \& Michael, 1975; Gabella, 1985; Kachave et al., 2009). The mulard has sufficiently thick LMM which contain a large number of blood vessels (Eyhab et al., 2017). The domestic duck (Khaleel \& Atiea, 2017) and chicken's (Alshamy, 2018) LMM "was weakly developed and appeared to be almost nonexistent". The notion of the 
absence of a submucosal base in the wall of a bird's intestine allowed some researchers to conclude that it had a three- or four-layered structure of its muscular membrane (Gabella, 1985; Kachave et al., 2009). Such features of the microscopic structure of the intestinal wall may be a species characteristic, which is associated with the trophic specialization and the corresponding nature of the processes of digestion and peristalsis. At the same time, the presence of the submucosal base in the intestinal wall of the same species of birds - domestic hens is indicated by Kuleshov, 2010, and its absence is indicated by Hodges \& Michael (1975), Gabella (1985), Kachave et al. (2009).

According to the results of our studies, the submucosal base is absent from the wall of the goose gut. The histological specimens between the LMM and the inner layer of the musculature reveal only a narrow strip of amorphous substance. It was detected only in the form of a narrow strip of amorphous substance between the LMM and inner layer of the muscular tunic. The LMM was clearly separated from the muscular tunic and contained thin layers of loose connective tissue only in places where the submucosal nerve plexus (nerve nodes and fibers) were located. Consequently, the outer layer of LMM of the small intestine is directly adjacent to the inner layer of muscular tunic due to the lack of submucosal base.

Considering the above, the following should be noted. Accordingly, it is not always possible to clearly separate the LMM on transverse sections of the intestinal wall. But on the longitudinal slides of the gut, it is noticeable that the unstriated muscle cells of the inner (circular) layer of the muscular tunic form bundles separated from each other by thin layers of loose connective tissue; while the outer layer of LMM is in the form of a continuous thin stripe. In addition, the LMM is more intensely stained by azure II - eosin, as well as by Mallory compared to staining of the muscular tunic.

\section{Conclusions}

The insignificant number of studies devoted to the structure of the LMM, as well as the considerable contradictions regarding the peculiarities of its structure and even its presence indicate the relevance and need for further studies in this area to clarify the importance of this structure of in the functioning of the intestine. The information about the peculiarities of the LMM structure of the goose gut can be used to evaluate comparison with other species of birds, the state of the digestive apparatus in the postnatal ontogeny, to understand pathological processes, to carry out diagnostic and prophylactic measures, to establish the action mechanism of environmental factors on the body of animals, as well as breeding work.

\section{References}

Accogli, G., Crovace, A. M., Mastrodonato, M., Rossi, G., Francioso, E. G., \& Desantis, S. (2018). Probiotic supplementation affects the glycan compositeon of mucins secreted by Brunner's glands of the pig duodenum. Annals of Anatomy, 218, 236-242.

Al-Saffar, F. J., \& Al-Samawy, E. R. M. (2016). Histomorphological and histochemical study of the small intestine of the striated scope owls (Otus scors brucei). Singapore Journal of Chemical Biology, 5, 1-10.

Al-Samawy, E. R. M., Al-Saffar, F. J., Naji, W. A., \& Jarad, A. S. (2017). Histomorphological and histochemical study of the small intestine of the mallard (Anas platyrhynchos) in South Iraq. International Journal of Science and Nature, 8(4), 757-764.

Alshamy, Z., Richardson, K. C., Hünigen, H., Hafez, H. M., Plendl, J., \& Al Masri, S. (2018). Comparison of the gastrointestinal tract of a dual-purpose to a broiler chicken line: A qualitative and quantitative macroscopic and microscopic study. PLoS One, 13(10), e0204921.

Bello, A., \& Danmaigoro, A. (2019). Histomorphological observation of the small intestine of red sokoto goat: A review. International Journal of Neurology Research and Therapy, 2(5), 1-7.

Bezuidenhout, A. J. (1990). A light microscopic and immunocytochemical study of the gastrointestinal tract of the ostrich (Struthio camelus). Onderstepoort Journal of Veterinary Research, 57, 37-48.

Bruhin-Feichter, S., Meier-Ruge, W., Martucciello, G., \& Bruder, E. (2012). Connective tissue in gut development: A key player in motility and in intestinal desmosis. European Journal of Pediatric Surgery, 22(6), 445-459.
Casteleyn, C., Doom, M., Lambrechts, E., Van den Broeck, W., Simoens, P., \& Cornillie, P. (2010). Locations of gut-associated lymphoid tissue in the 3month-old chicken: A review. Avian Pathology, 39(3), 143-150.

Cheled-Shoval, S. L., Amit-Romach, E., Barbakov, M., \& Uni, Z. (2011). The effect of in ovo administration of mannan oligosaccharide on small intestine development during the pre- and posthatch periods in chickens. Poultry Sciences, 90(10), 2301-2310.

Chen, W., Lu, C., Hirota, C., Iacucci, M., Ghosh, S., \& Gui, X. (2017). Smooth muscle hyperplasia/hypertrophy is the most prominent histological change in crohn's fibrostenosing bowel strictures: A semiquantitative analysis by using a novel histological grading scheme. Journal of Crohn's and Colitis, 11(1), 92-104.

Chin, A. M., Hill, D. R., Aurora, M. E., \& Spence, J. R. (2017). Morphogenesis and maturation of the embryonic and postnatal intestine. Seminars in Cell and Developmental Biology, 66, 81-93.

Ducatelle, R., Goossens, E., De Meyer, F., Eeckhaut, V., Antonissen, G., Haesebrouck, F., \& Van Immerseel, F. (2018). Biomarkers for monitoring intestinal health in poultry: Present status and future perspectives. Veterinary Research, 49, 43.

Greenwood, B., \& Davison, J. S. (1987). The relationship between gastrointestinal motility and secretion. American Journal of Physiology, 252, G1-G7.

Grundy, D., Al-Chaer, E. D., Aziz, Q., Collins, S. M., Ke, M., Tache, Y., \& Wood, J. D. (2006). Fundamentals of neurogastroenterology: Basic science. Gastroenterology, 130, 1391-1411.

Hodges, R. D., \& Michael, E. (1975). Structure and histochemistry of the normal intestine of the fowl. The fine structure of the duodenal crypt. Cell and Tissue Research, 160, 125-138.

Hussein, S., \& Rezk, H. (2016). Macro and microscopic characteristics of the gastrointestinal tract of the cattle egret (Bubulcus ibis). International Journal of Anatomy and Research, 4(2), 2162-2174.

Igwebuike, U. M., \& Eze, U. U. (2010). Morphological characteristics of the small intestine of the African pied crow (Corvus albus). Animal Research International, 7(1), 1116-1120.

Kachave, C. D., Bhosle, N. S., Mamde, C. S., \& Lambate, S. B. (2009). Histological observations on small intestine in broiler and layer of poultry birds. Royal Veterinary Journal of India, 5, 5-9.

Kamikawa, Y., Uchida, K., \& Shimo, Y. (1985). Heterogeneity of muscarinic receptors in the guinea pig esophageal muscularis mucosae and ileal longitudinal muscle. Gastroenterology, 88(3), 706-716.

Khaleel, I. M., \& Atiea, G. D. (2017). Morphological and histochemical study of small intestine inindigenous ducks (Anas platyrhynchos). IOSR Journal of Agriculture and Veterinary Science, 10(7), 19-27.

King, C. E., Glass, L. C., \& Townsend, S. E. (1947). The circular components of the muscularis mucosae of the small intestine of the dog. American Journal of Physiology, 148(3), 667-674.

Kuleshov, K. A. (2010). Postnatalnyiy morfogenez organov zheludochno-kishechnogo trakta kur pri primenenii selensoderzhaschih preparatov [Postnatal morphogenesis of the organs of the gastrointestinal tract of chickens when using selenium-containing preparations]. Veterinarnaya Patologiya, 1, 57-66 (in Russian).

Kuriyama, H., Kitamura, K., Itoh, T., \& Inoue, R. (1998). Physiological features of visceral smooth muscle cells, with special reference to receptors and ion channels. Physiological Reviews, 78, 811-920.

Kushch, M. M. (2015). Osoblyvosti mikroskopichnoi budovy kyshkivnyka husei [The peculiarities of microscopic structure of geese's gut]. Scientific Messenger of Lviv National University of Veterinary Medicine and Biotechnologies named after S. Z. Gzhytskyj, 17(3), 75-83 (in Ukrainian).

Lane, B. P., \& Rhodin, J. A. G. (1964). Fine structure of the lamina muscularis mucosae. Journal of Ultrastructure Research, 10(5-6), 489-497.

Lembo, A., \& Camilleri, M. (2003). Chronic constipation. The New England Journal of Medicine, 349, 1360-1368.

Lilburn, M. S., \& Loeffler, S. (2015). Early intestinal growth and development in poultry. Poultry Science, 94, 1569-1576.

Liu, B. Y., Wang, Z. Y., Yang, H. M., Wang, X. B., \& Lu, J. (2010). Developmental morphology of the small intestine in Yangzhou gosling. African Journal of Biotechnology, 43, 7492-7500.

Okpe, C. G., Abiaezute, N. C., \& Adigwe, A. (2016). Evaluation of the morphological adaptations of the small intestine of the African pied crow (Corvus albus). The Journal of Basic and Applied Zoology, 75, 54-60.

Pandit, K., Dhote, B. S., Mahanta, D., Sathapathy, S., Tamilselvan, S., Mrigeshand, M., \& Mishra, S. (2018). Histological, histomorphometrical and histochemical studies on the large intestine of uttara fowl. International Journal of Current Microbiology and Applied Sciences, 7(3), 1477-1491.

Percy, W. H., Burakoff, R., Rose, K., Desai, H. P., Pothoulakis, C., \& Eglow, R. (1998). In vitro evidence that rabbit distal colonic muscularis mucosae has a Clostridium difficile toxin A receptor. American Journal of Physiology, 275(3), 402-409. 
Schmidt, C. J., Persia, M. E., Feierstein, E., Kingham, B., \& Saylor, W. W. (2009). Comparison of a modern broiler line and a heritage line unselected since the 1950s. Poultry Science, 88(12), 2610-2619.

Schoffen, J. P., Vicentini, F. A., Marcelino, C. G., Araújo, E. J., Pedrosa, M. M., \& Natali, M. R. (2014). Food restriction beginning at lactation interferes with the cellular dynamics of the mucosa and colonic myenteric innervation in adult rats. Annals of the Brazilian Academy of Sciences, 86(4), 1833-1848.

Singh, S. P., Katiyar, R. S., Farooqui, M. M., Kumar, P., \& Prakash, A. (2017) Histogenesis of guinea fowl duodenum. Indian Journal of Poultry Science, 52(2), 193-198.

Strizhikov, V. K., Ponomareva, T. A., \& Nohovitsina, E. A. (2007). Morfofunktsionalnyie osobennosti rosta massyi i lineynyih pokazateley uchastkov tonkoy i tolstoy kishok u vodoplavayuschih ptits [Morphological and functional features of the growth of mass and linear indices of small and large intestine sections in waterfowl]. Vestnik Veterinarii, 1, 75-78 (in Russian).

Teirlynck, E., Gussem, M. D., Dewulf, J., Haesebrouck, F., Ducatelle, R., \& Van Immerseel, F. (2011). Morphometric evaluation of "dysbacteriosis" in broilers. Avian Pathology, 40(2), 139-144.

Tootian, Z., Sadeghinezhad, J., Sheibani, M. T., Fazelipour, S., De Sordi, N., \& Chiocchetti, R. (2013). Histological and mucin histochemical study of the small intestine of the Persian squirrel (Sciurus anomalus). Anatomical Science International, 88(1), 38-45.

Trifonov, N. A., \& Kuleshov, K. A. (2008). Postnatalnyiy morfogenez dvenadtsatiperstnoy kishki kur pri primenenii selensoderzhaschih preparatov [Postnatal morphogenesis of duodenum of chickens when using selenium-containing drugs]. Vestnik Altayskogo Gosudarstvennogo Agrarnogo Universiteta, 3(41), 33-36 (in Russian).

Uchida, K., \& Kamikawa, Y. (2007). Muscularis mucosae - the forgotten sibling. Journal of Smooth Muscle Research, 43(5), 157-177.

Udoumoh, A. F., Igwebuike, U. M., \& Ugwuoke, W. I. (2016). Morphological features of the distal ileum and ceca of the common pigeon (Columba livia). Journal of Experimental and Clinical Anatomy, 15, 27-30.

Uni, Z., Noy, Y., \& Sklan, D. (1995). Posthatch changes in morphology and function of the small intestines in heavy- and light-strain chicks. Poultry Science, 74(10), 1622-1629.

Van Montfrans, C., Peppelenbosch, M., Te Velde, A. A., \& Van Deventer, S. (2002). Inflammatory signal transduction in Crohn's disease and novel therapeutic approaches. Biochemical Pharmacology, 64(5-6), 789-795.

Verdal, H., Mignon-Grasteau, S., Jeulin, C., Le Bihan-Duval, E., Leconte, M. Mallet, S., Martin, C., \& Narcy, A. (2010). Digestive tract measurements and histological adaptation in broiler lines divergently selected for digestive efficiency. Poultry Science, 89, 1955-1961.

Websky, M. W., Kalff, J. C., \& Schäfer, N. (2015). Current knowledge on regulation and impairment of motility after intestinal transplantation. Current Opinion in Organ Transplantation, 20(3), 303-317.

Wilkinson, N., Dinev, I., Aspden, W. J., Hughes, R. J., Christiansen, I., Chapman, J., Gangadoo, S., Moore, R. J., \& Stanley, D. (2018). Ultrastructure of the gastro intestinal tract of healthy Japanese quail (Coturnix japonica) using light and scanning electron microscopy. Animal Nutrition, 4, 378-387. 